\title{
EXPRESSION AND FUNCTIONAL INTERACTION OF CHICKEN RbAP46 POLYPEPTIDE WITH HISTONES, HISTONE DEACETYLASE-1, AND HISTONE ACETYLTRANSFERASE-1
}

\author{
Ahyar Ahmad ${ }^{1, *}$ and Harningsih Karim ${ }^{2}$ \\ ${ }^{1}$ Department of Chemistry, Hasanuddin University, \\ Jl. Perintis Kemerdekaan Km. 10 Makassar, 90245, South Sulawesi, Indonesia \\ ${ }^{2}$ Department of Pharmacy, School of Pharmacy Yamasi Makassar, 90222, South Sulawesi, Indonesia
}

Received February 15, 2012; Accepted June 25, 2013

\begin{abstract}
In this study, we cloned and sequenced cDNA encoding the chicken p46 polypeptide, RbAp46. The cDNA encoding a protein consists of 424 amino acids is a member of the WD protein family, with seven WD repeat motifs, and exhibits $90.3 \%$ identity to RbAp48, and $94.3 \%$ identity to the human RbAp46. The RbAp46 fusion protein were synthesized by in vitro translation system and in Escherichia coli under induction by $50 \mu M$ IPTG and single step purified with glutathione-Agarose beads, showed that GST-tagged protein of approximately $72 \mathrm{kDa}$. The in vitro experiment established that RbAp46 interacts with chicken histones, chHDAC-1, and chHAT-1. The in vitro immunoprecipitation experiment, involving truncated mutants of RbAp46, revealed not only that two regions comprising amino acids 33-179 and 375-404 are necessary for its binding to $\mathrm{H} 2 \mathrm{~B}$, but also that two regions comprising amino acids 1-32 and 405-424 are necessary for its binding to H4. Furthermore, the GST pulldown affinity assay, involving truncated mutants of RbAp46, revealed that a region comprising amino acids 359-404 binds to chHAT-1 in vitro. Taken together, these results indicate not only that RbAp46 should participate differentially in a number of DNA-utilizing processes through interactions of its distinct regions with histones and chHAT-1, but also that the proper propeller structure of RbAp46 is not necessary for its interaction with chHAT-1.
\end{abstract}

Keywords: chromatin; immunoprecipitation experiment; histones; propeller structure

\section{ABSTRAK}

Pada penelitian ini, kami mengkloning dan menentukan urutan cDNA dari gen yang menyandi subunit p46, RbAp46 pada sel ayam DT40. Hasil penelitian menunjukkan bahwa RbAp46 mengandung sejumlah 424 residu asam amino yang terdiri dari tujuh motif WD dan memiliki masing-masing 90,3\% dan 94,3\% homologi dengan RbAp48 dan RbAp46 dari manusia. Protein RbAp46 dapat disintesis dengan sistem in vitro translasi dan diekspresikan pada sel E. coli yang diinduksi oleh $50 \mu$ M IPTG dan dimurnikan dengan glutathione-Agarosa menghasilkan protein sekitar $72 \mathrm{kDa}$. Penelitian secara in vitro menunjukan bahwa protein RbAp46 dapat berinteraksi dengan protein histon, HDAC-1, dan HAT-1. Residu asam amino 33-179 dan 375-404 dari RbAp46 merupakan daerah yang penting untuk berikatan dengan histon H2B, sedangkan residu asam amino 1-32 dan 405424 dari RbAp46 merupakan daerah yang penting untuk berikatan dengan histon H4. Selanjutnya dengan uji afinitas GST pulldown menunjukan bahwa residu asam amino 359-404 dari protein RbAp46 merupakan daerah terikatnya HAT-1 secara in vitro. Dari hasil penelitian tersebut dapat memberikan informasi tidak hanya adanya perbedaan partisipasi protein RbAp46 pada interaksinya dengan histon dan HAT-1 dalam proses aktivitas DNA, tetapi juga bahwa struktur propeller RbAp46 tidak penting pada proses interaksi dengan HAT-1.

Kata Kunci: kromatin; eksperimen immunopresipitasi; histon; struktur propeller

\section{INTRODUCTION}

Alterations in chromatin structure are preferentially involved in the regulation of cell functions, including gene expression in eukaryotes. In recent years, knowledge concerning the characteristics of the p48 subunit of CAF-1 (CAF-1p48, rename of RbAp48), which has seven WD repeat motifs and is a member of the WD

* Corresponding author. Tel/Fax : +62-411-586-498

Email address : ahyar1@yahoo.com

protein family, in numerous DNA-utilizing processes has been accumulated [1]. RbAp48 was identified as a polypeptide that is tightly associated with the catalytic subunit of human histone deacetylase- 1 and 2 (HDAC1 and 2) [2]. On the other hand, RbAp46 and RbAp48 are highly homologous histone chaperones that play key roles in protein complexes that function to establish and maintain chromatin structure. They are integral 
subunits of protein complexes that either add or remove acetyl moieties from the $\varepsilon$-amino groups of lysine residues on the flexible $\mathrm{N}$-terminal tail of histone $\mathrm{H} 4$, and they are also key components of histone methylases. RbAp46 binds to and enhances the activity of the type B histone acetyltransferase HAT1, an enzyme that acetylates histone $\mathrm{H} 4$ specifically at lysine residues 5 and 12 prior to their incorporation into nucleosomes during replication [3]. This specific pattern of acetylation of newly synthesized histone $\mathrm{H} 4$ is conserved from yeast to humans [4]. The importance of this modification is indicated by the crucial role HAT1 plays in the cellular resistance to genotoxic agents [5-6]. RbAp48, on the other hand, is an evolutionarily conserved subunit of the chromatin assembly factor- 1 (CAF-1) complex, where it associates with two other subunits, known as p150 and p60 in human cells. Like RbAp46, RbAp48 also contributes to a large number of other protein complexes within the cell, and they are sometimes both found in the same protein complex. Intriguingly, although RbAp46 and $\mathrm{RbAp} 48$ are $90 \%$ identical at the amino acid sequence level, in both human and yeast cells RbAp46 is found exclusively in complexes with HAT1, whereas RbAp48 is instead found in the CAF-1 complex [7]. Both $\mathrm{RbAp} 46$ and RbAp48 are found in the catalytic cores of histone deacetylase (HDAC) complexes that promote transcriptional repression of target genes, including those repressed by the retinoblastoma tumor suppressor protein [8-9].

Recently, we have found that chicken RbAp48, interact with chHDAC-1 and 2 in vivo, in an immunoprecipitation experiment followed by Western blotting [10]. Furthermore, the GST pulldown affinity assay, involving deletion mutants of both RbAp48 and chHDAC-2, revealed not only that RbAp48 binds to two regions of chHDAC-2 comprising amino acids 82-180 and 245-314, respectively, but also that two N-terminal, two C-terminal, or one $\mathrm{N}$-terminal and one C-terminal WD repeat motif of RbAp48 are required for this in vitro interaction. On the other hand, the p46 polypeptide (p46), renamed of RbAp46, which is a RbAp48 homolog, together with the latter, is contained in repressor complexes with HDAC-1 and 2, and mSin3 (the mammalian homolog of $\mathrm{Sin} 3$ ), $\mathrm{Rb}$ (the retinoblastoma protein), or Mi2 plus MeCP2, to repress transcription [11]. Retinoblastoma Associated protein 46, RbAp46, is a nuclear protein that has been shown to interact directly with retinoblastoma protein, $\mathrm{Rb}$, and is a component of the $\mathrm{mSin} 3$ corepressor complex as are the histone deactylase proteins (HDACs).

In this study we cloned cDNA encoding the chicken p46, RbAp46, comprising 424 amino acids including a putative initiation Met, exhibiting $90.3 \%$ homology to chCAF-1p48, and carrying seven WD repeat motifs. The RbAp46 polypeptide fusion protein were synthesized in
Escherichia coli with induction by $50 \mu \mathrm{M}$ IPTG and single step purified with glutathione-Agarose, showed that protein of approximately $72 \mathrm{kDa}$, were dramatically synthesis in Escherichia coli BL-21 cells. The in vitro experiment established that RbAp46 interacts with chicken histones, chHDAC-1, and chHAT-1. The in vitro immunoprecipitation experiment, involving truncated mutants of RbAp46, revealed not only that two regions comprising amino acids 33-179 and 375404 are necessary for its binding to $\mathrm{H} 2 \mathrm{~B}$, but also that two regions comprising amino acids 1-32 and 405-424 are necessary for its binding to H4. The GST pulldown affinity assay revealed not only that chp46, as well as chCAF-1p48, associates with chHAT-1, but also that a C-terminal region, comprising amino acids $359-404$ is essential for this interaction. These results suggest not only that the proper propeller structure of $\mathrm{RbAp} 46$, probably due to its WD repeat motifs, should not be necessary for its in vitro interaction with chHAT-1, but also that chp46 should be involved in a number of DNA-utilizing processes in distinct manners.

\section{EXPERIMENTAL SECTION}

\section{Materials}

pBluescript II SK(-) and pCite4a(-) were purchased from Stratagene and Novagen, respectively. pGEX-2TK plasmid and glutathione-Agarose beads were a product of Amersham Pharmacia Biotech. Single Tube Protein ${ }^{\mathrm{TM}}$ System 3 was purchased from Novagen. Radioisotope $\left[{ }^{35} \mathrm{~S}\right]$-Met and fluorographic reagents were purchased from Amersham Pharmacia Biotech. Anti-HA beads and anti-FLAG antibody were purchased from Santa Cruz, Biotech, Inc.

\section{Instrumentation}

Instruments that used in this study are DNA sequencing (Perkin-Elmer) Applied Biosystems Division, model 310 for sequencing of cDNA. PCR machine were used for genes cloning and preparation DNA plamid mutants, Electrophoresis apparatus and Immunoprecipitation Apparatus were used for proteinprotein interaction analysis. Autoclave, clean bench, Shimadzu UV/Vis spectrometer model UV-2600, and shaker incubator were used for DNA determination and bacterial preparation, respectively.

\section{Procedure}

Cloning and sequencing of cDNA encoding RbAp46

A PCR product of $435 \mathrm{bp}$, corresponding to a part of the coding region of huRbAp46, was first prepared from chicken DT40 cDNA, using sense and antisense 
A

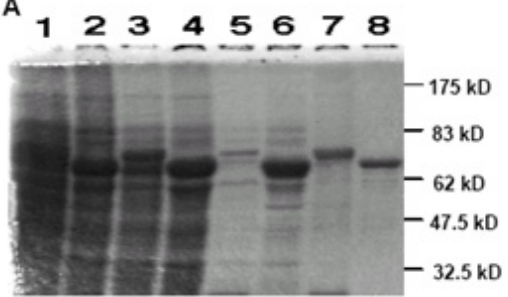

B

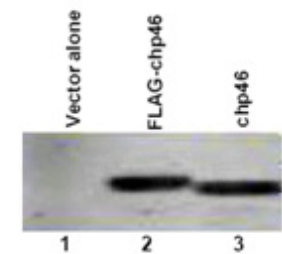

Fig 1. Expression followed SDS gel electrophoretic patterns of GST-RbAp46 (A) and FLAG-RbAp46 fusion protein (B).

oligonucleotide primers containing sequences 5'-CTGATGATCAGAAACTTATGATATGGG-3' and 5'-AGCAAATGACCCAAG GTTCATTGGG-3', respectively, which were constructed based on the amino acid sequences (DDQKLMIWD and PNEPWVICS) in huRbAp46 deduced from its cDNA [12]. To obtain full-length RbAp46 cDNA, using the resultant PCR product as a probe, we screened the DT40 lambda ZAP II cDNA library [10] as described [13]. The entire nucleotide sequences of both strands of the largest cDNA insert were sequenced by the dye terminator method (Applied Biosystems Division, Perkin Elmer).

\section{Plasmids construction}

We constructed the pCiteRbAp46 and/or pCiteFLAGRbAp46 plasmid carrying the gene encoding chp46 as described $[10,14]$. First a sense primer containing Ncol (5') with the sequence 5'-CCATGGCGAGTA AGGAAGTGCTGGAGG-3' and an antisense primer containing Sall (3') with the sequence 5'-CTCGAGTTACTGTCCTTGACCTTCCAG-3' were constructed. Next we prepared the DNA fragment encoding the full-length coding region of RbAp46 by PCR using the parental plasmid ( $\mathrm{pB}(\mathrm{II}) \mathrm{SKp} 46)$ carrying the full-length RbAp46 cDNA as a template with these primers, followed by digestion with Ncol plus Sall. We replaced the resultant $\mathrm{Ncol} / \mathrm{Sall}$ fragment with the Ncol/Sall fragment of the pCiteFLAGp48 plasmid carrying the gene encoding chCAF-1p48 [15]. The deletion mutants of RbAp46 were obtained as described [15]. We also use pCiteHAH2A, pCiteHAH2B, pCiteHAH3, pCiteHAH4, pCiteHAHDAC-1 and pCiteHAp60 were obtained as described $[10,15]$. Expression of the RbAp46 in E. coli bacteria and by in vitro translation system $E$. coli $\mathrm{BL}-21$ cells were transformed with pGEX-2TKchp46 and pGEX2TKchHAT-1, respectively, harboring the full-length RbAp46 and chHAT-1 cDNAs, and grown to $\mathrm{A}_{600} \mathrm{~nm}_{\mathrm{m}}=\sim 0.2$ in $400 \mathrm{~mL}$ of LB medium supplemented with $200 \mu \mathrm{g} / \mathrm{mL}$ ampicillin. After induction by the addition of $50 \mu \mathrm{M}$ isopropyl ß-D-thiogalactopyranoside (IPTG) overnight at $20{ }^{\circ} \mathrm{C}$, the cells were collected by centrifugation and purification by glutathione-Agarose

beads, essentially as described [10]. To produce $\left[{ }^{35} \mathrm{~S}\right]$ Met-labeled RbAp46 by in vitro translation system, a Single Tube Protein ${ }^{\mathrm{TM}}$ System 3 (Novagen) was used.

\section{Immunoprecipitation experiment and GST pulldown affinity assay}

The in vitro binding assays were performed, by using immunoprecipitation experiment and GST pulldown affinity assay essentially as described [10], in $200 \mu \mathrm{L}$ of the bead-binding buffer.

\section{RESULT AND DISCUSSION}

\section{Cloning of cDNA Encoding Chicken RbAp46}

To study the characteristics of RbAp46, we cloned and sequenced cDNA encoding it. Based on conserved amino acid sequences in human RbAp46 and mouse RbAp46 [11], we prepared the 435 bp PCR fragment, corresponding to a part of cDNAs encoding human RbAp46 and mouse RbAp46, by PCR using cDNAs from DT40 cells. Sequence analysis of the largest cDNA insert of $1799 \mathrm{bp}$ among them revealed that the clone contained both an initiation codon and a $3^{\prime}$ poly (A) tail, and also appeared to contain the fulllength RbAp46 cDNA sequence. The amino acid sequence deduced from the nucleotide sequence, comprising 424 residues including a putative initiation Met. This chicken RbAp46 polypeptide exhibits $94.3 \%$ identity in amino acid sequences to human RbAp46 and mouse RbAp46, and $90.4 \%$ identity to chicken and human RbAp48 $[10,16]$.

\section{Expression of Recombinant Chicken RbAp46 in E. coli and by in vitro Translation System}

First, to construct a chimeric plasmid, pGEX-2TK RbAp46, expressing the GST-RbAp46 fusion protein, RbAp46 cDNA was subcloned into the pGEX-2TK plasmid in frame. GST fusion proteins were synthesized in E. coli bacteria, extracted, and purified essentially as described previously [10]. As shown in Fig. 1A, the electrophoretic patterns on SDS-PAGE of whole cell lysates before and after induction with IPTG revealed that GST-RbAp46 fusion proteins of approximately $72 \mathrm{kD}$ were dramatically accumulated in E. coli BL-21 cells containing the pGEX-2TK RbAp46 plasmid. In lane 1 and 2, whole cell lysate of BL-21 cells containing the pGEX-2TK RbAp46 and pGEX2TKchHAT-1 plasmid without induction by IPTG, lane 3 and 4, lysate of BL-21 cells containing the pGEX2TKRbAp46 and pGEX-2TKchHAT-1 plasmid with induction by $50 \mu \mathrm{M}$ IPTG, lane 5 and 6 , complex beads containing RbAp46 and HAT-1, lane 7 and 8, RbAp46 

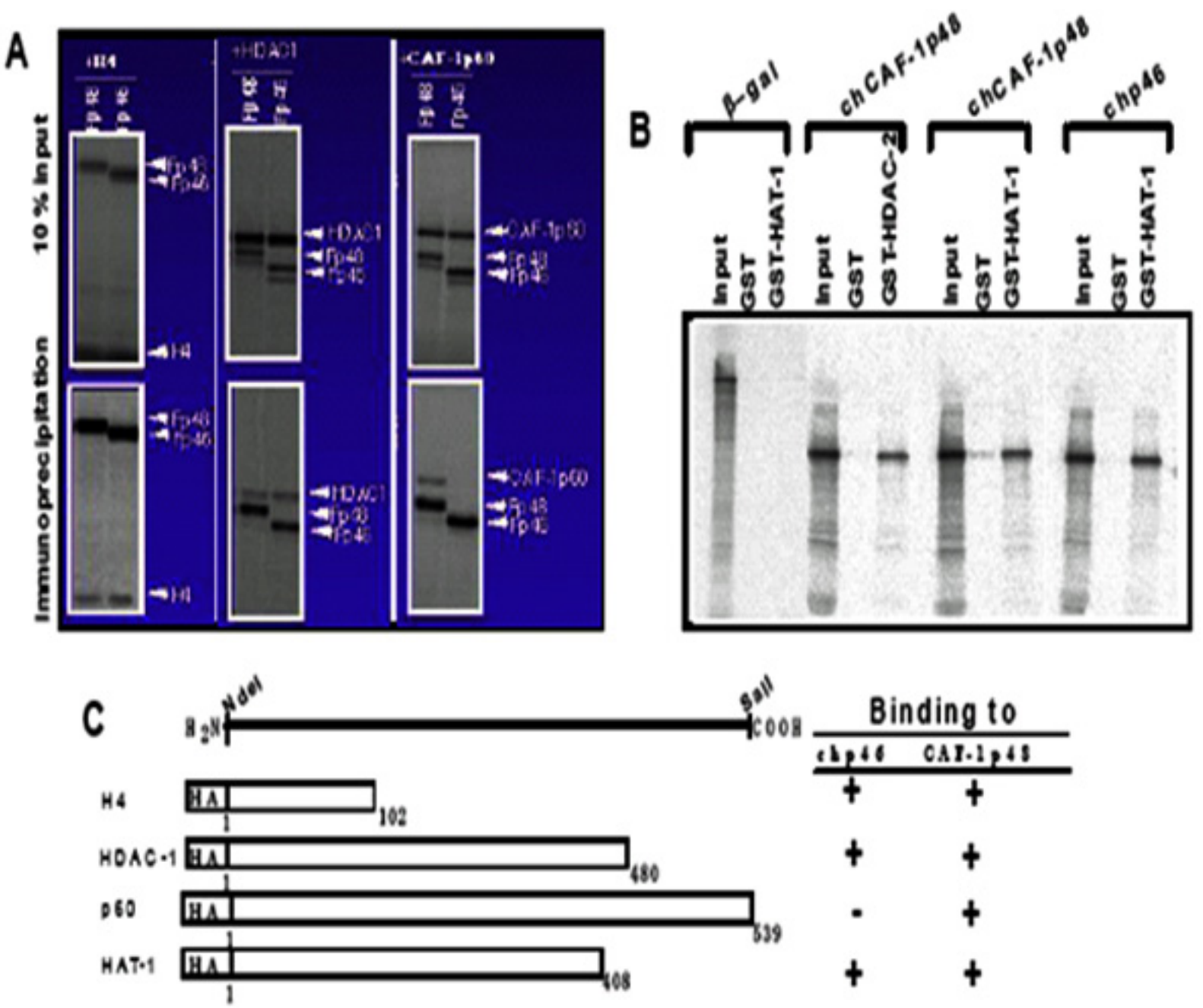

Fig 2. In vitro interaction of RbAp46 with histone H4, HDAC-1, CAF-1p60 and HAT-1

and chHAT-1 fraction respectively, purified with glutathione-agarose beads. In this data revealed, the GST-RbAp46 fusion proteins were purified to more than 95\% homogeneity, using glutathione-Agarose beads (see lane 7 in Fig. 1A). Furthermore, RbAp46 also have high and stable expression level by in vitro transcription and translation system (Fig. 1B).

\section{In vitro Interaction of RbAp46 with Histones, HDAC-1, CAF-1p60 and HAT-1}

We have revealed that RbAp48 binds to chHDACs [10] and chHAT-1 (17) in vivo and in vitro. On the other hand, it has been reported that a heterodimer of human RbAp46 and HAT-1 is involved in the chemical modification of core histones with acetyl groups, especially in the acetylation of Lys-5 and Lys-12 of histone $\mathrm{H} 4$ [18]. Therefore, to determine whether or not RbAp46 bound to these chromatin-related proteins, such as histone H4, HDAC-1 and CAF-1p60, we carried out an in vitro immunoprecipitation experiment, using $\left[{ }^{35}\right.$ S]Met-labeled FLAG-tagged RbAp46 and $\left[{ }^{35}\right.$ S]Metlabeled HA-tagged histones, HDAC-1 and CAF-1p60. As shown in Fig. 2A and $2 \mathrm{C}, \mathrm{RbAp} 46$ bound to histone $\mathrm{H} 4$ and HDAC-1 but not to CAF-1p60. To determine whether or not the RbAp46 polypeptide, together with RbAp48 as a positive control, bound also to HAT-1, the GST pulldown affinity assay was carried out.

$\mathrm{RbAp} 46$ was translated in vitro in the presence of $\left[{ }^{35} \mathrm{~S}\right] \mathrm{Met}$, and then assayed its ability to interact with HAT-1. As shown in Fig. 2B and 2C, the GST-HAT-1 fusion protein bound to RbAp46, as well as the binding activity of RbAp48 to HDAC-2 and HAT-1 as a positive control, whereas under the same conditions $ß-$ galactosidase did not bind to it.

Two regions, two other regions and one distinct region of RbAp46 are necessary for the interaction with $\mathrm{H} 2 \mathrm{~B}, \mathrm{H} 4$ and HAT-1. Next, we determined the region(s) of RbAp46 necessary for its binding ability as to $\mathrm{H} 2 \mathrm{~B}$, $\mathrm{H} 4$ and HAT-1, because the interaction of RbAp46 with 


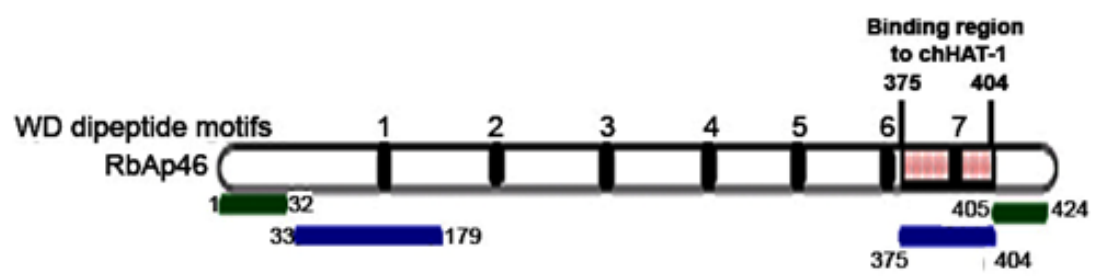

: Essential regions for binding to $\mathrm{H} 4$

: Essential regions for binding to $\mathrm{H} 2 \mathrm{~B}$

Fig 3. Essential regions of the RbAp46 for interaction with histone $H 2 B$ and $H 4$, and $H A T-1$

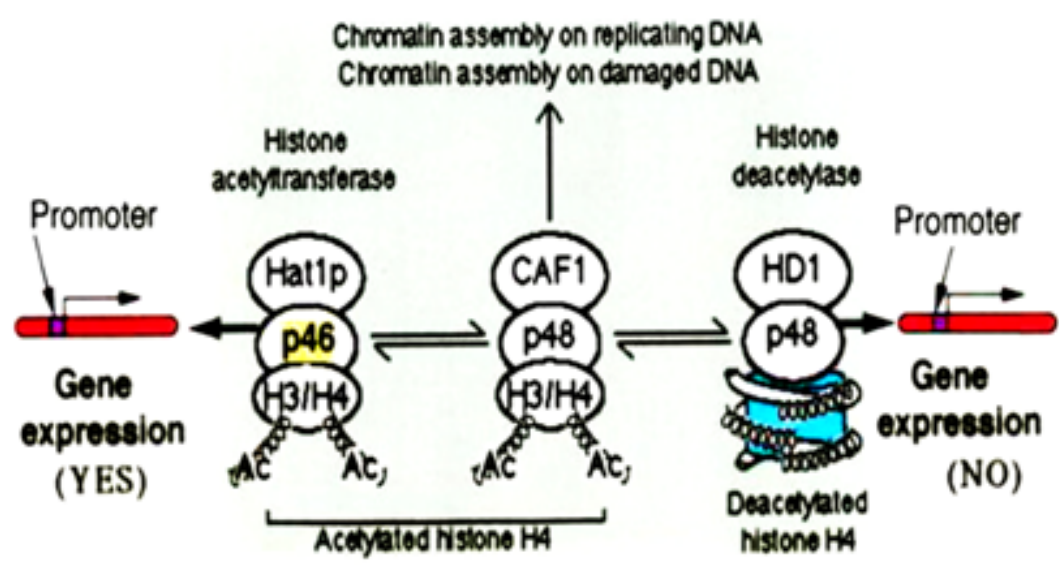

Fig 4. Model of a key role of RbAp46 protein on chromatin assembly and control of gene expression

one or more of these proteins could be thought to play a key role in the DNA-utilizing processes. We constructed C-terminal and N-terminal truncated mutants of FLAGtagged $\mathrm{RbAp46}$, and studied their in vitro interaction with the $\mathrm{H} 2 \mathrm{~B}, \mathrm{H} 4$ and $\mathrm{HAT}-1$ protein. $\mathrm{An}$ in vitro immunoprecipitation experiment, involving truncated mutants of RbAp46, revealed not only that two regions comprising amino acids 33-179 and 375-404 are necessary for its binding to $\mathrm{H} 2 \mathrm{~B}$, but also that two regions comprising amino acids 1-32 and 405-424 are necessary for its binding to $\mathrm{H} 4$ (Fig. 3). Furthermore, a GST pull down affinity assay, involving truncated mutants of $\mathrm{RbAp} 46$, revealed that a region comprising amino acids $375-404$ bind to HAT-1 in vitro (Fig. 3).

These results indicate not only that RbAp46 should participate differentially in a number of DNA-utilizing processes through the interaction of its distinct regions with $\mathrm{H} 2 \mathrm{~B}, \mathrm{H} 4$ and $\mathrm{HAT}-1$, but also that the propeller structure of RbAp46, based on the WD repeat motifs, is not necessary for its interaction with HAT-1.

As illustrated in Fig. 4, if RbAp46 protein bound to HAT-1 caused acetylation of chromatin on $\mathrm{H} 3 / \mathrm{H} 4$ induces an open conformation that allows the expression of gene activity. Oppositely, if RbAp48 protein bound to HDAC-1 caused deacetylation of chromatin structure induces on close conformation that allows the stop of gene expression. While the overall effect of RbAp46 is to increase expression of repressed genes, the overall effect of RbAp48 is to decrease their expression of repressed genes. In spite of these opposing activities on gene expression, RbAp46 and RbAp48 can act in concert to regulate gene expression [19]. The decreased association of RbAp46 with the Sox9 gene, which increases Sox 9 expression, and the continued association of RbAp48 with the Sox9 gene, which decreases Sox9 expression, would have the overall effect of repressing expression of this gene. The ability of $\mathrm{RbAp} 46$ and RbAp48 to interact with histones, HDACs and HAT-1 and facilitate protein-protein interactions [20], and expression RbAp46 facilitates stress-induced apoptosis of cancer cells [21] may also help to foster the assembly of protein complexes at gene regions involved in transcriptional control.

\section{CONCLUSION}

In summary, RbAp46 should be involved in numerous DNA-utilizing processes in different manners for its binding to $\mathrm{H} 2 \mathrm{~B}, \mathrm{H} 4$ and $\mathrm{HAT}-1$, and the proper propeller structure of RbAp46 is not necessary for the interaction with HAT-1.

\section{ACKNOWLEDGEMENT}

The author wishes to express sincere gratitude to Dr. Tatsuo Nakayama and Dr. Yasunari Takami for 
excellent support, advice, and inspiration for this research. Thank to H.K. Barman for editorial reading of the manuscript. This work was supported in part by Program Academic Recharging (PAR) program of the Ministry of Education and Culture of Indonesia and the Ministry of Education, Sciences, Sports and Culture of Japan.

\section{REFERENCES}

1. Smith, S., and Stillman, B., 1989, Cell, 58, 1, 15-25.

2. Taunton, J., Hassiq, C.A., and Schreiber, S.L., 1996, Science, 272, 5260, 408-411.

3. Verreault, A., Kaufman, P.D., Kobayashi, R., and Stillman, B., 1998, Curr. Biol., 8, 2, 96-108.

4. Benson, L.J., Gu, Y., Yakovleva, T., Tong, K., Barrows, C., Strack, C.L., Cook, R.G., Mizzen, C.A., and Annunziato A.T., 2006, J. Biol. Chem., 281, 14, 9287-9296.

5. Barman, H.K., Takami, Y., Ono, T., Nishijima, H., Sanematsu, F., Shibahara, K., and Nakayama, T., 2006, Biochem. Biophys. Res. Commun., 345, 4, 1547-1557.

6. Benson, L.J., Phillips, J.A., Gu, Y., Parthun, M.R., Hoffman, C.S., and Annunziato, A.T., 2007, J. Biol. Chem., 282, 2, 836-842.

7. Kaufman, P.D., Kobayashi, R., and Stillman, B., 1997, Genes Dev., 11, 345-357.

8. Korenjak, M., Taylor-Harding, B., Binné, U.K., Satterlee, J.S., Stevaux, O., Aasland, R., WhiteCooper, H., Dyson, N., and Brehm, A., 2004, Cell, $119,2,181-193$.
9. Nicolas, E., Morales, V., Magnaghi-Jaulin, L., Harel-Bellan, A., Richard-Foy, H., and Trouche, D., 2000, J. Biol. Chem., 275, 13, 9797-9804.

10. Ahmad, A., Takami, Y., and Nakayama, T., 1999, J. Biol. Chem., 274, 23, 16646-16653.

11. Martínez-Balbás, M.A., Tsukiyama, T., Gdula, D., and Wu, C., 1998, Proc. Natl. Acad. Sci. U.S.A., 95, 1, 132-137.

12. Qian, Y.W., and Lee, E.Y., 1995, J. Biol. Chem., 270, 43, 25507-25513.

13. Sambrook, J., Fritsch, E.F., and Maniatis, T., 1989, Molecular Cloning: A Laboratory Manual, Cold Spring Harbor Laboratory Press, Cold Spring Harbor, NY.

14. Takami, Y., Kikuchi, H., and Nakayama, T., 1999, J. Biol. Chem., 274, 23977-23990.

15. Ahmad, A., Takami, Y., and Nakayama, T., 2000, Biochem. Biophys. Res. Commun., 279, 1, 95-102.

16. Verreault, A., Kaufman, P.D., Kobayashi, R., and Stillman, B., 1996, Cell, 87, 1, 95-104.

17. Ahmad, A., Nagamatsu, N., Kouriki, H., Takami, Y., and Nakayama, T., 2001, Nucleic Acids Res., 29, 3, 629-637.

18. Parthun, M.R., Widom, J., and Gottschling, D.E., 1996, Cell, 87, 1, 85-94.

19. Parthun, M.R., 2007, Oncogene, 26, 5319-5328.

20. Creekmore, A.L., Walt, K.A., Schultz-Norton, J.R, Ziegler, Y.S., McLeod, I.X., Yates, J.R., and Nardulli, A.M., 2008, Mol. Cell. Endocrinol., 291, 12, 79-86.

21. Li, G-C., Guan, L-S., and Wang, Z-Y., 2003, Int. J. Cancer, 105, 6, 762-768. 